\title{
Fair and Equitable Treatment and (Full) Protection and Security in African Investment Treaties Between Generality and Contextual Specificity
}

\author{
Eric De Brabandere
}

Leiden University, The Netherlands

e.de.brabandere@law.leidenuniv.nl

\begin{abstract}
This article seeks to test whether African investment treaties present a specific approach - i.e. distinct from the North-American and Western Hemisphere - to fair and equitable treatment (FET) and (full) protection and security (FPS). The first main argument is that the concepts of FET and FPS are not substantially impacted by the mere fact of being included in investment agreements to which African States are party. The second main argument is that the understanding, interpretation and definitions of these concepts within Africa is not fundamentally different than in other regions. Thirdly, notwithstanding the similarity in the wording of these standards of treatment in African investment treaties, there may still be room for taking into account the specific circumstances of the States in which the investment is made, including the level of development of the host State.
\end{abstract}

\section{Keywords}

fair and equitable treatment - full protection and security - investment treaties developing States

* Professor of International Dispute Settlement, Grotius Centre for International Legal Studies, Leiden University; Attorney-at-Law (Member of the Ghent Bar).

(C) DE BRABANDERE, 2017 | DOI 10.1163/22119000-12340050

This is an open access article distributed under the terms of the prevailing CC-BY-NC license at the time of publication. 


\section{Introduction}

Fair and equitable treatment (FET) without doubt is the most invoked standard in investment treaty arbitration. Its importance, as a standard of investment protection, can therefore not be underestimated. While the (full) protection and security (FPS) standard is less invoked in isolation of FET, it has in the past played an important role in relation to investments affected by armed conflict, ${ }^{1}$ including conflicts in Africa. ${ }^{2}$

There is a notable and rather neat distinction between the formulation of FET and FPS in both North-American investment treaties and 'Western Hemisphere' bilateral investment treaties (BITs) which are used in European States. The latter tend to include FET as a stand-alone standard of treatment, while North-American investment treaties, as exemplified inter alia in the North-American Free Trade Agreement (NAFTA) ${ }^{3}$ and the US Model BIT 2012, ${ }^{4}$ tend to equate FET with the customary norm on the international minimum standard of treatment which includes providing (full) protection and security. In addition to North-American investment treaties and 'Western Hemisphere'BITs, The United Nations Conference on Trade and Development (UNCTAD) considered in a 2005 study, that a third approach is found in South-South BITs which however differs only limitedly from the preceding two models. This article seeks to test that finding and its relevance today, by investigating whether African investment agreements present a specific approach that is distinct from the North-American and Western Hemisphere. It will test this hypothesis in relation to the FET and FPS standards of treatment.

The main argument of this article is that the concepts of FET and FPS are not substantially impacted by the mere fact of being included in investment agreements between African and third States. The main reason for this, as I will explain, is that African States usually make no use of their own model BIT and thus, when negotiating and signing BITs with third States, use is made of the model BITs of the European or North-American partner States.

1 Asian Agricultural Products Ltd v Republic of Sri Lanka, ICSID Case No ARB/87/3, Final Award (27 June 1990) para 5o.

2 American Manufacturing \& Trading, Inc v Republic of Zaire, ICSID Case No ARB/93/1, Award (21 February 1997).

3 North American Free Trade Agreement (signed 17 December 1992, entered into force 1 January 1994) (1993) 32 ILM 289, 606 (NAFTA).

4 US Model Bilateral Investment Treaty (2012) < www.ustr.gov/sites/default/files/BIT\%2otext \%2ofor\%20ACIEP\%2oMeeting.pdf $>$ accessed 17 February 2017. 
As far as intra-African investment agreements are concerned, or SouthSouth investment agreements, it will be argued that here again little difference can be found in the FET and FPS provisions, which not only is linked to the same fact that African States usually make no use of their own model BIT, but also that they have generally followed the European approach to investment treaties and therefore taken over the main provisions of these treaties.

The article's second argument is that, notwithstanding the relative absence of any Africa-specific FET or FPS concepts in BITs, the understanding, interpretation and definitions of these concepts within Africa is not fundamentally different than in other regions.

Finally, I will argue that, again notwithstanding the similarity in the wording of these standards of treatment, these standards of treatment may be of particular relevance to African States, and more generally for developing States, from a practical perspective since these standards of treatment leave room for taking into account the specific circumstances of the host States, including its level of development.

I will first explain the main features of the FET and FPS treatment standards, and their relevance for African investment relations. I will then analyse, based on concluded investment treaties, whether there are Africa-specific formulations of the FET and FPS standards, whether there are Africaspecific interpretations of these provisions, and thirdly, how FET and FPS allow taking into account the specific circumstances of the States in which the investment is made, which may be of relevance for African states.

\section{The FET and FPS Standards of Treatment}

\section{$1.1 \quad$ Overview}

FPS, the international minimum standard (IMS) and FET share many features. The exact relation between FPS, the IMS and FET is still subject to much debate. It has been contented that FPS forms part of the IMS, ${ }^{5}$ or that

5 See for a discussion Christoph Schreuer, 'Full Protection and Security' (2010) 1(2) JIDS 353. See also the decision of the Tribunal in Noble Ventures which argued that ' $[w]$ ith regard to the Claimant's argument that the Respondent breached Art II (2)(a) of the BIT which stipulates that the "Investment shall ... enjoy full protection and security", the Tribunal notes: that it seems doubtful whether that provision can be understood as being wider in scope than the general duty to provide for protection and security of foreign nationals found in the customary international law of aliens', Noble Ventures, Inc v Romania, ICSID Case No ARB/o1/11, Award (12 October 2005) para 164. 
FET and FPS are included in the IMS. ${ }^{6}$ Others have contended on the contrary that all three standards of treatment are independent treaty standards. ${ }^{7}$ I do not intend to settle these controversies here.

FPS and FET (and IMS) are generally referred to as non-contingent, absolute or objective standards of treatment as opposed to contingent, relative or subjective standards, such as national treatment or most favoured nation (MFN) treatment. ${ }^{8}$ The latter category of standards of treatment impose on the host State the obligation to act in a certain way by reference to how other investors or investments are treated, e.g. national investors or investments in case of national treatment, or investors or investments from third States in case of MFN treatment. The objective of such standards is that States may not discriminate between investors and investments; whether or not the State has exercised due diligence in this respect is irrelevant. Objective standards, such as FET and FPS, on the other hand require from the State to act in a certain 'objective' way, as required under international law (either custom or treaty law) irrespective of how other investors or investments are treated. There is in other words no comparison with the treatment of other investors or investments. This is precisely why, as I will explain in the last Section, FET and FPS allow for the taking into account of the specific circumstances of the host State.

The FET standard is a flexible and rather vague concept. However, it is generally accepted that the legitimate expectations of the foreign investor form a key element of FET, ${ }^{9}$ as are obligations of due process, transparency, freedom from coercion and harassment, stability, predictability and a general duty of due diligence. ${ }^{10}$ FET requires at least treatment in accordance with the IMS as understood in general international law. ${ }^{11}$

6 See North American Free Trade Agreement (NAFTA) Free Trade Commission, 'Notes of Interpretation of Certain Chapter 11 Provisions' (31 July 2001) < www.sice.oas.org/tpd/ nafta/Commission/CH11understanding_e.asp $>$ accessed 17 February 2017.

$7 \quad$ See Schreuer (n 5$) 353$.

8 See Campbell McLachlan, Laurence Shore and Matthew Weiniger, International Investment Arbitration: Substantive Principles (OUP 2008) para 7.19 and Nicolas Angelet, 'Fair and Equitable Treatment' in Rüdiger Wolfrum (ed), Max Planck Encyclopedia of Public International Law (OUP 2012) vol III, para 3.

9 Andrew Newcombe and Lluis Paradell, Law and Practice of Investment Treaties: Standards of Treatment (Kluwer Law International 2009) 279.

$10 \quad$ ibid 277; Ioana Tudor, The Fair and Equitable Treatment Standard in the International Law of Foreign Investment (OUP 2008) 157 and 186. See also for an overview of the contents of the standard in function of arbitral practice Katia Yannaca-Small, 'Fair and Equitable Treatment Standard: Recent Developments' in August Reinisch (ed), Standards of Investment Protection (OUP 2008) 111, 118 et seq.

11 Newcombe and Paradell (n 9) 277. 
In practical terms, there are roughly four models of FET clauses, except for the possibility of course to not include any FET provision at all such as in the Australia-Singapore Free Trade Agreement of 2003. ${ }^{12}$ First, FET can be a standalone (unqualified) clause, in that FET is included without any specific reference to another treaty standard or to its content. ${ }^{13}$ Because of their standalone and unqualified character tribunals usually interpret such clauses very broadly. ${ }^{14}$ Secondly, FET can be coupled to the phrase 'in accordance with international law'.15 Such clauses are aimed at ensuring that the interpreter uses principles of international law, including, international customary law and general principles of law to identify the scope and content of the standard. ${ }^{16}$ Thirdly, FET can be equated to the IMS as is the case, for instance, in the 2012 US Model BIT. ${ }^{17}$ And fourthly, FET can be used in combination with some

12 Unless indicated otherwise, all investment treaties referred to here are available at UNCTAD, 'International Investment Agreements Navigator' < http://investmentpolicyhub .unctad.org/IIA > accessed 17 February 2017.

13 See, eg, Agreement between the Belgium-Luxembourg Economic Union and the Republic of Tajikistan on the Reciprocal Promotion and Protection of Investments (signed 12 February 2009, not yet in force) art 3 ('All investments made by investors of one Contracting Party shall enjoy a fair and equitable treatment in the territory of the other Contracting Party').

14 See, for a discussion, Matthew C Porterfield, 'A Distinction without a Difference? The Interpretation of Fair and Equitable Treatment Under Customary International Law by Investment Tribunals' (Investment Treaty News, 22 March 2013) <www.iisd .org/itn/2013/03/22/a-distinction-without-a-difference-the-interpretation-of-fair-and -equitable-treatment-under-customary-international-law-by-investment-tribunals/o > accessed 17 February 2017.

15 See, eg, Agreement between the Government of the Republic of Croatia and the Government of the Sultanate of Oman on the Promotion and Reciprocal Protection of Investments (signed 4 May 2004, not yet in force) art 3(2) ('Investments or returns of investors of either Contracting Party in the territory of the other Contracting Party shall be accorded fair and equitable treatment in accordance with international law and provisions of this Agreement.').

16 UNCTAD, Fair and Equitable Treatment (United Nations 2012) 22.

17 US Model BIT (n 4) art 5:

1. Each Party shall accord to covered investments treatment in accordance with customary international law, including fair and equitable treatment and full protection and security.

2. For greater certainty, paragraph 1 prescribes the customary international law minimum standard of treatment of aliens as the minimum standard of treatment to be afforded to covered investments. The concepts of "fair and equitable treatment" and "full protection and security" do not require treatment in addition to or beyond that 
specific substantive content, such as the prohibition of a denial of justice or non-discrimination. ${ }^{18}$

Provisions granting protection and security to investments and investors vary in nature. Some treaties refer to 'full protection and security', while others provide for 'protection and security' or 'constant protection and security'.19 As explained in regard to FET, it is not the purpose here to engage in a discussion of these variances. Thus, the standard will be referred to here as FPS despite the existing different wordings. Indeed, the current conception of the FPS standard of treatment - however phrased - comprises the obligation for States to provide physical or police protection to foreign investments and investors from harm caused by the State itself or by third parties which includes the obligations to prevent, punish and apprehend, as well as to possess and make available a functioning administrative and legal system to that effect. ${ }^{20}$ Some tribunals moreover have argued that the differences in wording do not make a substantive difference. ${ }^{21}$ Also, the use of 'protection' rather than 'protection and security' does not change the level of police protection a host State is required to provide. ${ }^{22}$ Besides the requirement of providing physical protection and security, certain tribunals have, in particular when the word 'full' precedes 'protection and security', extended the application of the standard to

which is required by that standard, and do not create additional substantive rights. The obligation in paragraph 1 to provide:

(a) "fair and equitable treatment" includes the obligation not to deny justice in criminal, civil, or administrative adjudicatory proceedings in accordance with the principle of due process embodied in the principal legal systems of the world.

18 See, eg, ASEAN Comprehensive Investment Agreement (signed 26 February 2009, entered into force 29 March 2012) art 11:

1. Each Member State shall accord to covered investments of investors of any other Member State, fair and equitable treatment and full protection and security.

2. For greater certainty:

(a) fair and equitable treatment requires each Member State not to deny justice in any legal or administrative proceedings in accordance with the principle of due process; and ...

19 For an overview and discussion, see Schreuer ( $\mathrm{n}_{5}$ ).

20 See UNCTAD, Bilateral Investment Treaties 1995-2006: Trends in Investment Rulemaking (United Nations 2007) 132. See also Jeswald W Salacuse, The Law of Investment Treaties (OUP 2010) 132 and 209-10 and George K Foster, 'Recovering Protection and Security: The Treaty Standard's Obscure Origins, Forgotten Meaning, and Key Current Significance' (2012) 45 Vanderbilt J Transnatl L 1095. 2007) para 354 . 
'legal protection and security', making this understanding of the standard in fact relatively similar to the FET standard. ${ }^{23}$ Legal protection and security, in certain interpretations, in essence would require States to refrain from taking legal or governmental acts or measures that would hinder the proper functioning of the investment or would contravene investor's rights. ${ }^{24}$ Certain case law suggests that FPS requires host States to provide to foreign investors a legal framework that guarantees legal protection to investors. ${ }^{25}$

1.2

\section{The Relevance and Importance of the FET and FPS Standards of Treatment}

FET without doubt is the most invoked standard in investment treaty arbitration, ${ }^{26}$ and this is not different in disputes involving African States. The FET standard thus plays an important role in investment disputes involving African States. As far as FPS is concerned, and more particularly the FPS standard's physical protection and security component, several African states have been confronted to civil strife and armed conflict over the past decades, and as a consequence the FPS clause has had ${ }^{27}$ and has a specific practical importance in claims opposing foreign investors to African States. Over the past years, States recovering from conflict have been confronted to claims by foreign investors for physical damages caused to investments during the conflict, or for other non-violent acts, which have decreased the economic value

23 CME Czech Republic BV v Czech Republic, UNCITRAL, Partial Award (13 September 2001) para 613; Ceskoslovenska Obchodni Banka, AS v The Slovak Republic, ICSID Case No ARB/97/4, Award (29 December 2004) para 170; Azurix Corp v The Argentine Republic, ICSID Case No ARB/o1/12, Award (14 July 2006) para 408; PSEG Global, Inc, The North American Coal Corporation, and Konya Ingin Electrik Üretim ve Ticaret Limited Sirketi v Republic of Turkey, ICSID Case No ARB/02/5, Award (19 January 2007) para 258; Enron Corporation and Ponderosa Assets, LP v Argentine Republic, ICSID Case No ARB/o1/3, Award (22 May 2007) para 323; Compañiá de Aguas del Aconquija SA and Vivendi Universal $S A v$ Argentine Republic (formerly Compañía de Aguas del Aconquija, SA and Compagnie Générale des Eaux v Argentine Republic), ICSID Case No ARB/97/3, Award (20 August 2007) para 7.4.15; Biwater Gauff (Tanzania) Ltd v United Republic of Tanzania, ICSID Case No ARB/05/22, Award (24 July 2008) para 729; National Grid plc v The Argentine Republic, UNCITRAL, Award (3 November 2008) para 189.

24 See, for a discussion, Schreuer (n 5) 358-36o and Newcombe and Paradell (n 9) 311 et seq.

25 Schreuer $\left(\mathrm{n}_{5}\right) 363$.

26 Newcombe and Paradell (n 9) 255 .

27 See, eg, American Manufacturing \& Trading, Inc v Republic of Zaire, ICSID Case No ARB/93/1, Award (21 February 1997) and Wena Hotels Ltd $v$ Arab Republic of Egypt, ICSID Case No ARB/98/4, Award (8 December 2000). 
of investments. ${ }^{28}$ It is precisely in view of the various internal armed conflicts and civil upheavals that have characterized the African continent over the past decades that the application of and respect for the FPS standard in Africa has become highly relevant. FPS, coupled or not with FET, indeed has been an often invoked provision in investment disputes involving African States, and has formed the basis of several decisions establishing breaches of investment treaties. ${ }^{29}$ But the importance of FPS not only lies in its application to acts during armed conflict or civil strife. It applies also in non-violent situations and has thus been invoked in that context as well. ${ }^{30}$

It's without doubt that FET and FPS may be worded differently, and that there is no uniform understanding of both concepts is beyond doubt. Clear differences exist between the two main approaches to investment treaties: the North-American conceptions of FET and FPS, which tend to equate FET with the customary norm on the international minimum standard of treatment, and 'Western Hemisphere'-approach of European States, which tends towards standalone FETs or towards combining FET with references to international law or some substantive content. UNCTAD however adds a third approach to

28 In the case of Algeria, for example, which was confronted to guerrilla warfare in certain parts of its territory since the 2000s, see LESI SpA and ASTALDI SpA v République Algérienne Démocratique et Populaire, ICSID Case No ARB/05/3, Award (12 November 2008). In the case of Tunisia, for example, see Lundin Tunisia BVv Republic of Tunisia, ICSID Case No ARB/12/30, Award (22 December 2015). Egypt likewise is confronted to some 9 claims by foreign investors following the civil unrest in the country over the past years, such as Asa International SpA $v$ Arab Republic of Egypt, ICSID Case No ARB/13/23 (registered 13 September 2013).

29 ibid.

30 In Waguih Elie George Siag and Clorinda Vecchi v Egypt, for example, the two Claimants had, after having learned that their investment was to be seized, requested protection of their investment from the Nuweibaa Police. Despite Egyptian Tribunal's decisions that the expropriated investment should be returned to the Claimant because of the illegality of the expropriation, Egypt did not restitute the investment to the Claimants. The Tribunal thus found Egypt to be in violation of its obligations under the 'full protection standard' as contained in Article 4(1) of the Italy-Egypt BIT, see Waguih Elie George Siag and Clorinda Vecchiv The Arab Republic of Egypt, ICSID Case No ARB/05/15, Award (1 June 2009) paras $45^{1-56 .}$ 
investment treaties, namely the one that can be found in South-South BITs, which are close to the European approach. ${ }^{31}$ According to UNCTAD, SouthSouth BITs, which includes intra-African BITs, would essentially differ from the preceding two models, in that they 'put more emphasis on exceptions (e.g. for balance-of-payments or prudential measures) and the so-called forkin-the-road clause. ${ }^{32}$ These distinctive features are alien to the standards of treatment under consideration here, and as the following overview will show, the concepts of FET and FPS are in general not substantially impacted by the mere fact of being included in intra-African BITs, nor in BITs concluded between African States and third States.

\subsection{Africa-Specific Formulations of FET and FPS}

An analysis of several BITs indicates that African States, when signing BITs with third States, do not generally deviate from existing conceptions of FET and FPS, in the sense that there does not seem to be any Africa-specific conception of the FET and FPS standards of treatment. The BIT negotiating partner's conception of the standard usually is incorporated in BITs between African States and third States. As a consequence, the investment protection provisions of investment agreements with African States generally follow the traditional BIT provisions in respect of the FET and FPS standards of protection of foreign investors, with the variations one finds in BITs generally, and there does not seem to be any streamlined use of one specific FET or FPS provision.

\subsubsection{BITs Between African and Non-African States}

BITs between European and African States generally follow the model of the European partner States, and one thus finds standalone FETs, ${ }^{33}$ FET linked to

31 UNCTAD, South-South Cooperation in International Investment Arrangements (United Nations 2005) 31.

32 UNCTAD, World Investment Report 2004: The Shift Towards Services (United Nations 2005) 224, Box VI.3.

33 See, eg, Accord entre l'Union économique belgo-luxembourgeoise et le Gabon concernant l'encouragement et la protection réciproques des investissements (signed 22 May 2002, entered into force 28 May 2005) art 3 (BLEU-Gabon BIT); Accord sur l'encouragement et la protection réciproque des investissements entre le Royaume des Pays-Bas et la République du Burundi (signed 24 May 2007, entered into force 1 August 2009) art 3 (Netherlands-Burundi BIT). 
international law, ${ }^{34}$ and FET linked to some substantive content. ${ }^{35}$ The same is true as far as FPS is concerned, BITs that African States have concluded contain the variations one finds in European BITs. ${ }^{36}$

The situation is not different as far as North-American-African BITs are concerned. For example, investment treaties signed between African States and the US largely follow the US Model BIT in its successive versions. Thus, in accordance with Article II (2) of the 1984 US Model BIT, ${ }^{37}$ which linked FET to international law, the US-Congo, ${ }^{38}$ US-Egypt $^{39}$ or US-Tunisia ${ }^{40}$ BITs include an FET clause that also linked it to international law. The more recent US-Rwanda BIT follows the 2004 US Model BIT ${ }^{41}$ linking FET, and FPS to the IMS. ${ }^{42}$ Similar findings can be made as far as Canadian-African BITs are

34 See, eg, Accord entre le Gouvernement de la République de Madagascar et le Gouvernement de la République française sur l'encouragement et la protection réciproques des investissements (signed 25 July 2003, entered into force 17 April 2005) art 3.

35 See, eg, Accord entre le Gouvernement du Royaume du Maroc et l'Union économique belgo-luxembourgeoise concernant l'encouragement et la protection réciproques des investissements (signed 13 April 1999, entered into force 29 May 2002) art 2(1) (BLEUMorocco BIT) (linking FET with no discrimination).

36 See, eg, BLEU-Gabon BIT (n 33) art 3 ('protection et sécurité constants'); NetherlandsBurundi BIT (n 33) art 3 ('sécurité et protection physique intégrale'); Agreement between the Government of the United Kingdom of Great Britain and Northern Ireland and the Government of the Republic of Angola for the Promotion and Protection of Investments (signed 4 July 2000, not yet in force) art 2 ('full protection and security'); Agreement between the Swiss Confederation and and the Republic of Botswana on the Promotion and Reciprocal Protection of Investments (signed 26 June 1998, entered into force 13 April 2000) art 4(1) ('full protection and security').

37 'Text of the US Model Treaty Concerning the Reciprocal Encouragement and Protection of Investment of February 24, 1984' (1986) 4 Berkeley J Intl L 136.

38 Treaty between the United States of America and the Republic of Zaire Concerning the Reciprocal Encouragement and Protection of Investment (signed 3 August 1984, entered into force 28 July 1989) art 2.

39 Treaty between the United States of America and the Arab Republic of Egypt Concerning the Reciprocal Encouragement and Protection of Investments (signed 11 March 1986, entered into force 27 June 1992) art 2.

40 Treaty between the United States of America and the Republic of Tunisia Concerning the Reciprocal Encouragement and Protection of Investment (signed 15 May 1990, entered into force 7 February 1993) art 2.

41 US Model BIT (2004) <www.state.gov/documents/organization/117601.pdf> accessed 17 February 2017.

42 Treaty between the Government of the United States of America and the Government of the Republic of Rwanda Concerning the Encouragement and Reciprocal Protection of Investment (signed 19 February 2008, entered into force 1 January 2012) art 5. 
concerned. They largely follow Canadian practice in relation to FET and FPS. Thus, the recent Canada-Benin BIT of $2013^{43}$ as well as the Canada-Cameroon ${ }^{44}$ and Canada-Nigeria ${ }^{45}$ BITs of 2014 follow the Canadian approach to FET and FPS as embodied in the Canadian Model FIPA, in that the treaties limit FET and FPS to what is required under the international customary minimum standard of treatment. ${ }^{46}$ Older Canadian-African BITs incorporate an FET clause linked to international law. ${ }^{47}$ Finally, BITs signed between African States and other third States, such as China or Singapore, do not contain any specific formulation of FET or FPS either. ${ }^{48}$

43 Agreement between the Government of Canada and the Government of the Republic of Benin for the Promotion and Reciprocal Protection of Investments (signed 9 January 2013, entered into force 12 May 2014) <http://international.gc.ca/trade-commerce/trade -agreements-accords-commerciaux/agr-acc/benin/fipa-apie/index.aspx?lang=eng> accessed 17 February 2017 (Canada-Benin BIT).

44 Agreement between Canada and the Republic of Cameroon for the Promotion and Protection of Investments (signed 3 March 2014, entered into force 16 December 2016) <http://international.gc.ca/trade-commerce/trade-agreements-accords-commerciaux/ agr-acc/cameroon-cameroun/fipa-apie/index.aspx?lang=eng > accessed 17 February 2017 (Canada-Cameroon BIT).

Agreement between Canada and the Federal Republic of Nigeria for the Promotion and Protection of Investments (signed 6 May 2014, not yet in force) <http://international .gc.ca/trade-commerce/trade-agreements-accords-commerciaux/agr-acc/nigeria/ fipa-apie/index.aspx?lang=eng $>$ accessed 17 February 2017 .

46 ibid, art 6; Canada-Benin BIT (n 43) art 7; Canada-Cameroon BIT (n 44) art 6.

47 See, eg, Agreement between the Government of the Republic of South Africa and the Government of Canada for the Promotion and Protection of Investments (signed 27 November 1995, not yet in force) art 2; Agreement between the Government of Canada and the Government of the Arab Republic of Egypt for the Promotion and Protection of Investments (signed 13 November 1996, entered into force 3 November 1997) art 2.

48 Chinese-African BITs largely have adopted the standalone FET clause. See, eg, Agreement between the Government of the People's Republic of China and the Government of the Republic of Ghana Concerning the Encouragement and Reciprocal Protection of Investments (signed 12 October 1989, entered into force 22 November 1990) art 3; Agreement between the Government of the People's Republic of China and the Government of the Republic of Benin Concerning the Encouragement and Reciprocal Protection of Investments (signed 18 February 2004, not yet in force) art 2; Agreement between the Government of the People's Republic of China and the Government of the Syrian Arab Republic concerning the Reciprocal Promotion and Protection of Investments (signed 9 December 1996, entered into force 1 November 2001) art 3. See also Agreement between the Government of the Republic of Mauritius and the Government of the Republic of Singapore (signed 4 March 2000, entered into force 19 April 2000) art 2(2) (containing a standalone FET clause). 
The main explanations for the absence of a specific formulation of FET and FPS in African investment treaties are, first - and I admit the circularity of the argument - that there is, perhaps, no specific understanding of FET and FPS in the investment policies of African States. Secondly, many African States do not have a model BIT which could be used for negotiations. As a consequence, in the context of investment treaty negotiations between African States and Canada or the US, African States have a tendency to 'simply' sign up to the model used by the respective other State. In other words, in many cases the model treaty is simply signed with little, if any, modifications to the FET and FPS clauses used in the models of the BIT partner States. The Canada-Benin BIT negotiations are a good example to highlight this circumstance. In fact, the negotiations lasted only a few months, ${ }^{49}$ and the final treaty text is very close to the Canadian Model FIPA. ${ }^{50}$ Rather exceptional are the recent negotiations between Canada and Burkina Faso that lasted almost two years from August 2012 to May 2014 - and the parties have not yet signed the final text of the investment treaty. 51

\subsubsection{Intra-African BITs}

Intra-African BITs which have effectively entered into force are a rather rare species, the majority of the BITs concluded with African States being indeed North-South BITs. Overall, the majority of intra-African BITs follow the European approaches to FET and FPS, and therefore one finds variations to FET and FPS in intra-African BITs. ${ }^{52}$ At the same time, in respect to FPS,

49 For a discussion, and criticism, see Lorenzo Cotula, 'Is the Tide Turning for Africa's Investment Treaties?' (International Institute for Environment and Development (IIED), 8 March 2013) <www.iied.org/tide-turning-for-africa-s-investment-treaties> accessed ${ }_{17}$ February 2017.

50 ibid.

51 See Government of Canada, Foreign Affairs, Trade and Development Canada, 'CanadaBurkina Faso Foreign Investment Promotion and Protection Agreement' <http:// international.gc.ca/trade-commerce/trade-agreements-accords-commerciaux/agr-acc/ burkina_faso/fipa-apie/background-contexte.aspx?lang=eng > accessed 17 February 2017 .

$5^{2}$ See, eg, Convention entre le Gouvernement de la République Arabe d'Egypte et le Gouvernement de la République Centrafricaine sur l'encouragement et la protection réciproques des investissements (signed 7 February 2000, not yet in force) art 2 (EgyptCentral African Republic BIT) (standalone FET); Accord entre le Gouvernement du Burkina Faso et le Gouvernement de la République du Benin concernant la promotion et la protection réciproque des investissements (signed 18 May 2001, not yet in force) art 2(1) (Burkina Faso-Benin BIT) (standalone FET); Agreement between the Government of the Federal Democratic Republic of Ehtiopia and the Government of the Republic of the 
one finds - besides general FPS clauses- ${ }^{53}$ treaties containing no FPS clause, ${ }^{54}$ FPS clauses connected to international law, ${ }^{55}$ and the inclusion of references to the fact that FPS standard does not apply to 'measures necessary to maintain public order. ${ }^{56}$ Such clauses are moreover not limited to intra-African BITs and one finds them in several other treaties signed between European and African States, in particular treaties signed by the Belgian-Luxembourg Economic Union (BLEU). ${ }^{57}$

Here again little difference can be found in the FET and FPS provisions, which is not only linked, again, to the fact that African States usually make no use of their own model BIT, but also to the fact that African States have generally followed the European approach to investment treaties and have therefore taken over the main provisions of these treaties. ${ }^{58}$ Based on this BIT practice, the understanding, interpretation and definitions of FET and FPS within Africa seem consequently not to be fundamentally different than in other regions.

Sudan on the Reciprocal Promotion and Protection of Investment (signed 7 March 2000, entered into force 15 May 2001) art 3 (FET followed by a national treatment and MFN clause); Accord entre le Gouvernement du Royaume du Maroc et le Gouvernement de la République du Cameroun sur l'encouragement et protection réciproques des investissements (signed 24 January 2007, not yet in force) art 2 (Morocco-Cameroon BIT) (FET linked to international law).

53 Accord entre le Gouvernement de la République du Cameroun et le Gouvernement de la République Arabe d'Egypte relatif à la promotion et la protection réciproques des investissements (signed 24 Octobre 2000, not yet in force) art 4.

54 See, eg, the Burkina Faso-Benin BIT ( n $_{52}$ ) or the Switzerland-Benin BIT of 1966.

55 Treaty between the Federal Republic of Germany and the Republic of Benin Concerning the Promotion and Reciprocal Protection of Capital Investment (signed 29 June 1978, entered into force 18 July 1985) art 3.

$5^{6}$ See, eg, Morocco-Cameroon BIT (n 52) art 2; Egypt-Central African Republic BIT (n $5^{2}$ ) art 2.

57 See, eg, Accord entre la République du Benin et l'Union économique belgo-luxembourgeoise concernant l'encouragement et la protection réciproques des investissements (signed 18 May 2001, entered into force 30 August 2007) art 3(2); Agreement between the Belgo-Luxembourg Economic Union and the Government of the Republic of Belarus on the Reciprocal Promotion and Protection of Investments (signed 9 April 2002, not yet in force) art 3(2).

58 UNCTAD (n 32) 224, Box VI.3. 
Regional African Investment Agreements and the SADC Model BIT

Contrary to the majority of the intra-African BITs, some regional African investment agreements do indicate an Africa-specific understanding of FET and FPS. However, not all African regional free trade agreements contain substantive investment protection provisions. The Treaty for the Establishment of the East African Community (EAC) from 1999 for instance contains commitments by which States parties agreed to adopt measures to achieve the free movement of persons and services, but does not contain substantive investment protection provisions. In those regional agreements, which include an FET or FPS provision, such as the COMESA Agreement ${ }^{59}$ or the SADC Protocol on Finance and Investment, ${ }^{60}$ these FET and FPS clauses do not indicate any specific deviance from the general formulations one finds in other investment agreements.

However, over the past years, certain African investment agreements show specific features in relation to FET and FPS, which may be seen as heralds of a possible specific African conception of these standards. The most important example here is the Investment Agreement for the COMESA ${ }^{61}$ Common Investment Area, ${ }^{62}$ which however has not entered into force. This treaty, first of all, has no FPS clause. Secondly, the agreement has a very specific FET clause, phrased as follows:

\section{ARTICLE 14 - Fair and Equitable Treatment}

1. Member States shall accord fair and equitable treatment to COMESA investors and their investments, in accordance with customary international law. Fair and equitable treatment includes the obligation not to

59 Treaty Establishing the Common Market for Eastern and Southern Africa (signed 5 November 1993, entered into force 8 December 1994) art 159 ('Investment Promotion and Protection') ('1. In order to encourage and facilitate private investment flows into the Common the Market, Member States shall: (a) accord fair and equitable treatment to private investors').

6o SADC Protocol on Finance and Investment (signed 18 August 2008, entered into force 16 April 2010, version before the amendments of August 2016) art 6 <www.sadc.int/ files/4213/5332/6872/Protocol_on_Finance_Investment2006.pdf > accessed 17 February 2017.

61 COMESA Member States are Burundi, Comoros, Democratic Republic of Congo (DR Congo), Djibouti, Egypt, Eritrea, Ethiopia, Kenya, Libya, Madagascar, Malawi, Mauritius, Rwanda, Seychelles, Sudan, Swaziland, Uganda, Zambia and Zimbabwe.

62 Investment Agreement for the COMESA Common Investment Area (signed 23 May 2007, not yet in force). 
deny justice in criminal, civil, or administrative adjudicatory proceedings in accordance with the principle of due process embodied in the principal legal systems of the world.

2. Paragraph 1 of this Article prescribes the customary international law minimum standard of treatment of aliens as the minimum standard of treatment to be afforded to covered investments and does not require treatment in addition to or beyond what is required by that standard.

3. For greater certainty, Member States understand that different Member States have different forms of administrative, legislative and judicial systems and that Member States at different levels of development may not achieve the same standards at the same time. Paragraphs 1 and 2 of this Article do not establish a single international standard in this context.

The first two paragraphs are reminiscent of a definition one regularly finds in US and Canadian BITs, as well as in the NAFTA, ${ }^{63}$ and thus signal adherence to a rather strict approach to FET. In that respect, one may argue that since the customary international minimum standard includes physical protection and security, the absence of a specific FPS clause in the COMESA Investment Agreement has no influence on the application of the customary physical protection and security standard. The third paragraph of the COMESA Investment Agreement however is interesting, since it includes a rather uncommon provision, which introduces a link between respecting the FET standard and the level of development of host State. ${ }^{64}$ This idea is not entirely new. As I will explain in the final Section of this article, there has generally been a discussion on the question of whether the level of development of the host State may be taken into account when assessing what investors can expect as treatment from the host State. ${ }^{65}$ While the idea thus already exists, it is rather uncommon

63 NAFTA (n 3) art 1105 ('Minimum Standard of Treatment'): 'Each Party shall accord to investments of investors of another Party treatment in accordance with international law, including fair and equitable treatment and full protection and security'. The NAFTA Free Trade Commission has interpreted this provision as follows: 'Article 1105(1) prescribes the customary international law minimum standard of treatment of aliens as the minimum standard of treatment to be afforded to investments of investors of another Party. (2) The concepts of "fair and equitable treatment" and "full protection and security" do not require treatment in addition to or beyond that which is required by the customary international law minimum standard of treatment of aliens.' (NAFTA Free Trade Commission (n 6) s B (1)-(2)).

$64 \quad$ UNCTAD (n 16$) 34$.

65 See infra pt 3 . 
to have such a provision in an investment agreement, and to that effect, it does indicate a special approach to the FET and FPS standard.

The SADC Model BIT ${ }^{66}$ also provides for a specific approach, not only on BITs in general, but more specifically on FET and FPS provisions. However, this model has not yet been used in practice. The SADC Model BIT takes again a rather strict approach to FET, and contains two options. The first one links FET to the customary IMS - in line with the US and Canadian practice - but contains in its second paragraph a definition of that customary IMS which incorporates almost verbatim the Neer formulation of that standard:67

\section{Article 5: Option 1: Fair and Equitable Treatment}

5.1. Each State Party shall accord to Investments or Investors of the other State Party fair and equitable treatment in accordance with customary international law on the treatment of aliens.

5.2. For greater certainty, paragraph 5.1 requires the demonstration of an act or actions by the government that are an outrage, in bad faith, a wilful neglect of duty or an insufficiency so far short of international standards that every reasonable and impartial person would readily recognize its insufficiency.

The Commentary to the SADC Model BIT is very informative in this respect. It states that the first option is 'based on the traditional fair and equitable treatment (FET) provision common to many BITs. ${ }^{68}$ The explicit reference to the Neer formulation here is intended to be more specific and precise in the

66 South African Development Community, 'SADC Model Bilateral Investment Treaty Template with Commentary' (2012) <www.iisd.org/itn/wp-content/uploads/2012/10/ SADC-Model-BIT-Template-Final.pdf> accessed 17 February 2017 (hereinafter: SADC Model BIT).

67 The United States-Mexico General Claims Commission described the IMS as follows in LFH Neer and Pauline Neer (USA) v United Mexican States, Decision (15 October 1926) (1951) IV UNRIAA 6o, 61-62):

the propriety of governmental acts should be put to the test of international standards, and (second) that the treatment of an alien, in order to constitute an international delinquency, should amount to an outrage, to bad faith, to willful neglect of duty, or to an insufficiency of governmental action so far short of international standards that every reasonable and impartial man would readily recognize its insufficiency. Whether the insufficiency proceeds from deficient execution of an intelligent law or from the fact that the laws of the country do not empower the authorities to measure up to international standards is immaterial. 
standard to be applied', and counters the fact that explicit references to customary international law generally, or the customary international law standard of treatment of aliens have not 'sufficed to restrain arbitrator creativity in this regard. 69

Option 2 is even narrower being limited to 'Fair Administrative Treatment', and denial of justice only:

Article 5: Option 2: Fair Administrative Treatment

5.1. The State Parties shall ensure that their administrative, legislative, and judicial processes do not operate in a manner that is arbitrary or that denies administrative and procedural [justice][due process] to investors of the other State Party or their investments [taking into consideration the level of development of the State Party].

5.2. Investors or their Investments, as required by the circumstances, shall be notified in a timely manner of administrative or judicial proceedings directly affecting the Investment(s), unless, due to exceptional circumstances, such notice is contrary to domestic law.

5.3. Administrative decision-making processes shall include the right of [administrative review] [appeal] of decisions, commensurate with the level of development and available resources at the disposal of State Parties.

5.4. The Investor or Investment shall have access to government-held information in a timely fashion and in accordance with domestic law, and subject to the limitations on access to information under the applicable domestic law.

5.5. State Parties will progressively strive to improve the transparency, efficiency, independence and accountability of their legislative, regulatory, administrative and judicial processes in accordance with their respective domestic laws and regulations.

In relation to the second option, the Commentary to the SADC Model BIT states that this 'is an alternative formulation that would be a new approach to addressing key issues in a more restricted and careful manner than the FET text. ${ }^{70}$ It is explicitly formatted as a reaction to the broad interpretations of FET provisions in other treaties, and aims at removing the discretion left to arbitrators to decide what FET means: 'the language on FET presented here

69 ibid.

70 ibid 23-24. 
is the least likely to lead to mischief through expansive interpretations by arbitrators. ${ }^{71}$

As far as FPS is concerned, the SADC Model BIT is interesting since it couples FPS with the national treatment and MFN treatment standards. Article 9 provides that

9.1. A State Party shall accord Investments of Investors of the other State Party protection and security no less favourable than that which it accords to investments of its own investors or to investments of investors of any third State.

9.2. Investors of one State Party whose Investments in the territory of the other State Party suffer losses as a result of a breach of paragraph 9.1, in particular owing to war or other armed conflict, revolution, revolt, insurrection or riot in the territory of the Host State shall be accorded by the Host State treatment, as regards restitution, indemnification, compensation or other settlement, no less favourable than that which the Host State accords to investors of any third State.

As the Commentary also indicates, this approach is not extraordinary, and one finds such formulations of FPS in many other investment agreements, ${ }^{72}$ also in relation to the FET standard. ${ }^{73}$ In essence, despite being promoted as a stand-alone clause, ${ }^{74}$ the protection and security clause does not seem to add anything substantial to an FPS clause limited to physical protection. An MFN clause generally is missing in the SADC Model BIT, based on the consideration that 'these should be bilateral treaties and that, as such, they should not establish unintended multilateralization through the MFN provision. ${ }^{75}$

\footnotetext{
$71 \quad$ ibid.

72 ibid 29.

73 See, eg, Accord entre le Gouvernement de la République du Cameroun et le Gouvernement de la République Populaire de Chine pour la promotion et la protection réciproques des investissements (signed 10 May 1997, entered into force 27 July 2014) art $3<\mathrm{http}: / / \mathrm{dev}$ .arbitration.org/sites/default/files/bit/cameroon_china_french.pdf $>$ accessed 17 February 2017.

74 SADC Model BIT (n 66) 29.

75 ibid 22. The Commentary nevertheless mentions that if States should wish to include an MFN provision, it suggests it to be drafted as follows:

4.2. Most Favoured Nation Treatment: Subject to paragraphs 4.4-4.6, each State Party shall accord to Investors and their Investments treatment no less favourable than the treatment it accords, in like circumstances, to investors of any other State and their
} 
More recently, SADC Member States have adopted certain important changes to the SADC Finance and Investment Protocol ${ }^{76}$, and notably to its Annex 1 which contains the investment protection standards. The changes as such have not (yet) been made public. ${ }^{77}$ The main change relevant for this article relates to Article 6.1 of Annex 1, which granted investors fair and equitable treatment. The FET standard has been removed and apparently replaced by a clause providing instead for national treatment. ${ }^{78}$ National treatment moreover is subjected to preferential treatment for local investors in case of domestic legislation adopted to further 'national development objectives.' ${ }^{79}$ The amended protocol has not yet been ratified, but the changes brought to the text may be seen, as is the case with the SADC Model BIT discussed above, as heralding a new direction for African - or more broadly for (developing) countries which are dissatisfied with the current investment protection standards - approaches to investment protection.

\subsection{Africa-Specific Interpretations of FET and FPS}

One may nonetheless question whether, notwithstanding the relative similarity in wording of the FET and FPS standards of treatment in BITs between African States and third States, African States have a different understanding of FET or FPS. This does not appear to be the case.

First of all, and this is the most important consideration, if African States had intended FET or FPS to mean something different than what is regularly understood by these standards in their different formulations, African States would have made it clear in the text of their treaties directly. Besides the just mentioned exceptions in the COMESA Investment Agreement - which has not entered into force - and the SADC Model BIT - which has not yet been

investments with respect to the management, operation and disposition of Investments in its territory.

76 SADC Protocol on Finance and Investment (signed 18 August 2006, entered into force 16 April 2010) <www.sadc.int/files/4213/5332/6872/Protocol_on_Finance_Investment 2006.pdf $>$ accessed 22 February 2017.

77 This paragraph is based on the report by Luke E Peterson, 'Investigation: In Aftermath of Investor Arbitration Against Lesotho, SADC Member-States Amend Investment Treaty so as to Remove ISDS and Limit Protections' (IAReporter, 20 February 2017) $<$ www.iareporter.com/articles/investigation-in-aftermath-of-investor-arbitration-against -lesotho-sadc-member-states-amend-investment-treaty-so-as-to-remove-isds-and-limit -protections/> accessed 22 February 2017.

78 ibid.

79 ibid. 
used in practice -, no different understanding has been noticeable from any of the treaty texts that presented in Section 2.1 here above. It is thus difficult to argue that, absent any additional indication in the treaty text or in the negotiation documents, an identically drafted provision would have a different meaning only because a State from a different continent is signatory to that treaty.

Second, statements made by African governments in arbitral proceedings do not indicate that FET or FPS have any specific or different meaning in the African continent. Indeed, arguments raised by States during arbitral proceedings by definition have a tendency to weaken the value and legal implications of the protection standards, and this is no different from one continent to another. ${ }^{80}$ This is, indeed, a question of litigation strategy rather than an indication of a different understanding of FET and FPS.

Third, arbitral tribunals usually interpret FET provisions without any specific geographical consideration. Reference is made to other tribunals' interpretation of the provision in disputes and no consideration is given to the question whether the parties to the cited decision are in fact geographically linked to the parties to the dispute at stake. ${ }^{81}$

\section{Contextualizing FET and FPS in Africa}

\subsection{FET and the Legitimate Expectations of Foreign Investors}

As explained under Section 1, FET is a flexible and rather vague concept. Nonetheless, it is generally accepted that the legitimate expectations of the foreign investor form part of FET. ${ }^{82}$ What constitutes 'legitimate expectations' is again subjected to diverse interpretations, covering expectations resulting from the host State's conduct in respect of commitments or representations made by the State, expectations of a certain stability and predictability in

$80 \quad$ See for a discussion and examples: Lise Johnson, 'Ripe for Refinement: The State's Role in Interpretation of FET, MFN, and Shareholder Rights' GEG Working Paper 2015/101 (April 2015) <http://ccsi.columbia.edu/files/2015/05/GEG-WP_101-Ripe-for-Refinement-The -States-Role-in-Interpretation-of-FET-MFN-and-Shareholder-Rights-Lise-Johnson_o .pdf> accessed 21 February 2017.

81 See, eg, Biwater Gauff $v$ Tanzania (n 23) paras 524-33 and Jan de Nul NV and Dredging International NVv Arab Republic of Egypt, ICSID Case No ARB/04/13, Award (6 November 2008) paras 185-94.

$82 \quad$ Newcombe and Paradell (n 9) 279. 
the legal and administrative framework of the host State, and the general circular - expectation of a fair and equitable conduct by the host State. ${ }^{83}$

As was shown in the previous Section, Article 14 (3) of the COMESA Investment Agreement contains a provision to the effect that FET is made dependent on the level of development of the host State. Besides the inclusion in a treaty of such a provision, one may validly argue that the legitimate expectations of foreign investors differ according to whether the investment is made in a developed or in a developing State, and that as a consequence the application of the FET standard, at least as far as the expectations of investors are concerned, is necessarily linked to the specific level of development of the host State. This is of course not limited to African States.

First, FET must be appreciated in concreto taking into account the specific circumstances of each case, both from a factual and from a contextual perspective. ${ }^{84}$ As one author puts it, 'the subjective element is the flesh that covers the carcass of the standard, giving it life. It is only when the FET standard is applied to a specific case that it becomes alive. ${ }^{15}$ Application of the FET standard should thus not only depend on the specific facts of the case, but more importantly on the circumstances and the context in which the investment was made. The latter assessment criterion includes the political and economic situation of the host State. Although this will be more visible in relation to the FPS standard because of the application of the due diligence standard, as I will explain in the next Section, there is no reason to exclude the influence of the level of development of the host State in relation to the FET standard. In this context, I should also point out that investors should act with due diligence in making the investment. ${ }^{86}$ The idea is a corollary to the mentioned principle that the legitimate expectations of foreign investors differ according to whether the investment is made in a developed or a developing State.

Case law in this respect however is limited. The Tribunal in Parkerings, for instance, noted that the foreign investor has

83 For a discussion, see ibid 279 et seq.

84 ibid 278. See also, amongst others, Jan de $N u l N V$ (n 81) para 185.

85 Tudor (n 10) 127. See also Ronald S Lauderv The Czech Republic, UNCITRAL, Final Award (3 September 2001) para 292. However, the use here of the notion 'subjective' may be misleading as it implies that the arbitrator's decision on what is fair and equitable is based only on the arbitrator's personal perception thereof, while it is beyond doubt that what fair and equitable treatment is should be based on legal reasoning through the interpretation of the relevant applicable investment treaty and general international law.

Tudor (n 10) 216. 
a right to a certain stability and predictability of the legal environment of the investment. The investor will have a right of protection of its legitimate expectations provided it exercised due diligence and that its legitimate expectations were reasonable in light of the circumstances. Consequently, an investor must anticipate that the circumstances could change, and thus structure its investment in order to adapt it to the potential changes of legal environment. ${ }^{87}$

In the same vein, the Tribunal in Biwater Gauff explained

Protection of legitimate expectations: the purpose of the fair and equitable treatment standard is to provide to international investments treatment that does not affect the basic expectations that were taken into account by the foreign investor to make the investment, as long as these expectations are reasonable and legitimate and have been relied upon by the investor to make the investment. ${ }^{88}$

The Tribunal in Eudoro Armando Olguín v Republic of Paraguay explained in relation to claims for violation of the FET standard and an expropriation claim that

This Tribunal does not accept Mr. Olguín's contention that he was induced to make his investment by the bulletins issued by the Central Bank of Paraguay. To the contrary, the Tribunal feels that prudence would have prompted a foreigner arriving in a country that had suffered severe economic problems to be much more conservative in his investments. ${ }^{89}$

\subsection{FPS and the Due Diligence Requirement}

Due diligence is present in a variety of aspects of the protection of foreign investors in international investment law. In the current conception of the FPS standard, the host state is in breach of its international obligation to guarantee FPS, if it fails to exercise due diligence in taking all necessary measures in order to provide physical and security protection to the foreign investor from

\footnotetext{
$87 \quad$ Parkerings-Compagniet AS $v$ Lithuania (n 21) para 333.

88 Biwater Gauff v Tanzania (n 23) para 602 (emphasis added).

89 Eudoro Armando Olguín v Republic of Paraguay, ICSID Case No ARB/98/5, Award (26 July 2001) para 75 .
} 
harm cause by third parties. ${ }^{90}$ Although FPS is often not further defined, it is the general understanding of the content of the standard that it requires the State to exercise due diligence. In Lauder v Czech Republic, for instance, the Tribunal noted that

Article II (2) (a) of the Treaty provides that '[i]nvestment ... shall enjoy full protection and security'. There is no further definition of this obligation in the Treaty. The Arbitral Tribunal is of the opinion that the Treaty obliges the Parties to exercise such due diligence in the protection of foreign investment as reasonable under the circumstances. However, the Treaty does not oblige the Parties to protect foreign investment against any possible loss of value caused by persons whose acts could not be attributed to the State. Such protection would indeed amount to strict liability, which can not be imposed to a State absent any specific provision in the Treaty. ${ }^{91}$

The host State thus holds no strict liability for such harm. ${ }^{92}$ A host State should thus take all measures that it could reasonably be expected to take in order to prevent the occurrence of damages to the foreign investor and its investment. ${ }^{93}$ The same principles apply to host State's obligations in case of armed conflict, civil strife, revolution or natural disasters. ${ }^{94} \mathrm{~A}$ host State should then use 'the police and military forces to protect the interests of the alien to the extent feasible and practicable under the circumstances, both before the event and while it unfolds. 95

Certain authors have argued that international law adheres, generally, to the diligens paterfamilias standard. ${ }^{96}$ In his 1955 Hague Academy Lecture, Freeman noted that the standard of due diligence requires 'nothing more nor less than the reasonable measures of prevention which a well-administered

\footnotetext{
9o See references in $\mathrm{n} 20$.

$91 \quad$ Lauderv Czech Republic (n 85) para 308.

92 Salacuse (n 20) 132 and 209-10. See also Asian Agricultural Products Ltd v Republic of Sri Lanka, ICSID Case No ARB $/ 87 / 3$, Final Award (27 June 1990) para 77.

93 Salacuse (n 20) 217.

94 Newcombe and Paradell (n 9) 336, para 13.4.

95 Rudolf Dolzer and Christoph Schreuer, Principles of International Investment Law (OUP 2008) 166.

96 Riccardo Pisillo-Mazzeschi, 'The Due Diligence Rule and the Nature of the International Responsibility of States (1992) 35 German YB Intl L 41.
} 
government could be expected to exercise under similar circumstances. ${ }^{97}$ This is an 'objective' assessment criterion.

The objective standard has however been rejected by several scholars and arbitrators, which have instead relied on the 'subjective due diligence standard', taking into consideration the means that are at the disposal of the host State, as well as the specific circumstances present in the host State. ${ }^{98}$ In assessing the due diligence standard, Brownlie supports the application of the diligentia quam in suis standard, rather than the diligens pater familias standard, ${ }^{99}$ arguing that the applicable standard is the standard ordinarily observed by the particular State in its own affairs, which means that variations in the wealth between States can be taken into account. ${ }^{100}$ This is in line with the application of the principle of other fields of international law, such as international environmental law. The International Law Commission (ILC), in its Draft Articles on Prevention of Transboundary Harm from Hazardous Activities, for instance, consider that the 'economic level of States is one of the factors to be taken into account in determining whether a State has complied with its obligation of due diligence', in relation to States' obligation of prevention, noting at the same time that 'a State's economic level cannot be used to dispense the State from its obligation.'101

Also, more recent cases suggest that the applicable standard is a subjective due diligence standard. In Lauder $v$ Czech Republic, the Tribunal considered that the FPS obligation 'obliges the Parties to exercise such due diligence in the protection of foreign investment as reasonable under the circumstances. ${ }^{102}$ In $C M E v C z e c h$ Republic, the Tribunal also explained that 'a government is only obliged to provide protection which is reasonable in the circumstances. ${ }^{103}$ Sole arbitrator Jan Paulsson in Pantechnikiv Albania also unambiguously adopted the subjective assessment method, distinguishing 'physical protection and security' from 'denial of justice', the latter not requiring to take into account the resources of the State, but the former allowing to take account of the resources of the State:

\footnotetext{
97 Alwyn V Freeman, 'Responsibility of States for Unlawful Acts of Their Armed Forces' (1955-II) 88 Recueil des Cours 263, 277-78.

98 See, for an overview, Newcombe and Paradell (n 9) 310, para 6.44.

99 Pisillo-Mazzeschi (n 96) 41.

$100 \quad$ Ian Brownlie, Principles of Public International Law (7th edn, OUP 2008) 526.

101 International Law Commission, 'Draft Articles on Prevention of Transboundary Harm from Hazardous Activities' (2001) UN GAOR 56th Session Supp No 10, UN Doc A/56/10, Commentary to art 3, para 13.

102 Lauderv Czech Republic (n 85) para 308 (emphasis added).

103 CME Czech Republic BVv Czech Republic (n 23) para 353 (emphasis added).
} 
A failure of protection and security is to the contrary likely to arise in an unpredictable instance of civic disorder which could have been readily controlled by a powerful state but which overwhelms the limited capacities of one which is poor and fragile. There is no issue of incentives or disincentives with regard to unforeseen breakdowns of public order; it seems difficult to maintain that a government incurs international responsibility for failure to plan for unprecedented trouble of unprecedented magnitude in unprecedented places. The case for an element of proportionality in applying the international standard is stronger than with respect to claims of denial of justice. ${ }^{104}$

\section{Conclusion}

FET and FPS constitute, from a substantive perspective, important protection standards in investment agreements, both generally and specifically in Africa investment relations.

In addition to North-American investment treaties and 'Western Hemisphere'-BITs which are used by European States, UNCTAD considers a third approach found in South-South BITs, which however differs from the preceding two models in other aspects than the standards under consideration here. Based on these starting points, this article's main attempt has been to investigate whether African investment agreements present a specific approach to FET and FPS in international investment agreements.

This article has argued that treaty practice, between African States and third States as well as between African States, shows no different conception of FET or FPS, in the sense that a specific African model would exist. It has, on the contrary been shown that in BITs between African and third States, the used FPS and FET clauses depend very much on the contracting third State, and in relation to intra-African BITs that they reflect the FET and FPS clauses usually found in European BITs.

The main explanations for the absence of a specific formulation of FET and FPS in African investment treaties are first, the absence, of a specific understanding of FET and FPS in the investment policies of African States, and secondly, the absence of African States' model BITs which are used for negotiations. Besides the mentioned exceptions in the recent COMESA Investment which has not entered into force- and the SADC Model BIT - which has not

104 Pantechniki SA Contractors \& Engineers $v$ The Republic of Albania, ICSID Case No ARB /07/21, Award (30 July 2009) para 77 . 
yet been used in practice -, a specific understanding of FET and FPS is not noticeable from the treaty text or from the arbitral practice.

This article finally has shown that in line with Article 14 (3) of the COMESA Investment Agreement which contains a provision to the effect that FET is made dependent on the level of development of the host State, FET and FPS may at any rate be interpreted and applied differently not in African States specifically, but in developing States more generally. Indeed, in relation to FET, I have argued that the legitimate expectations of foreign investors differ according to whether the investment is made in a developed or a developing State, and that as a consequence the application of the FET standard is linked to the specific level of development of the host State. In relation to FPS, I have argued that the due diligence standard used to assess whether the host State has taken all necessary measures to provide physical and security protection to the foreign investor from harm caused by third parties is the subjective diligentia quam in suis standard. This standard implies that variations in the wealth between States and the level of development of the States can be taken into account. 